\title{
Prevalence and risk factors of gastrointestinal parasites in backyard pigs reared in the Bucaramanga Metropolitan Area, Colombia
}

\author{
Prevalência e fatores de risco de parasitos gastrointestinais em suínos criados \\ na Área Metropolitana de Bucaramanga, Colombia \\ Juan Carlos Pinilla1* (D); Elsa Morales²; Nelson Uribe Delgado³; Angel Alberto Florez ${ }^{1}$ \\ ${ }^{1}$ Grupo de Investigación en Ciencias Agropecuarias - GICA, Facultad de Ciencias Exactas, Naturales y Agropecuarias, Universidad de \\ Santander, Bucaramanga, Colombia \\ ${ }^{2}$ Grupo de Investigación CliniUdes, Facultad de Salud, Universidad de Santander, Bucaramanga, Colombia \\ ${ }^{3}$ Grupo de Investigación en Epidemiología Molecular - GIEM, Facultad de Salud, Universidad Industrial de Santander, Bucaramanga, Colombia
}

How to cite: Pinilla JC, Morales E, Delgado NU, Florez AA. Prevalence and risk factors of gastrointestinal parasites in backyard pigs reared in the Bucaramanga Metropolitan Area, Colombia. Braz J Vet Parasito/ 2020; 29(4): e015320. https://doi.org/10.1590/ S1984-29612020094

\begin{abstract}
Backyard pigs have been associated with poor sanitary conditions and the development of parasitic diseases, often causing public health and food safety problems. Therefore, the aim of this study was to determine the prevalence and risk factors for gastrointestinal parasites in backyard pigs. 279 animals were sampled from thirtytwo backyard pig farms located in the Bucaramanga, Floridablanca, Giron and Piedecuesta municipalities, from Bucaramanga Metropolitan Area, Colombia. Fecal samples were taken directly from the rectum and processed by four coprological techniques. The overall prevalence of gastrointestinal parasites was $91 \%$, being the highest values for Balantidium coli and Eimeria sp. Regarding the prevalence by municipalities, there was no statistical association $(p \geq 0.05)$ indicating that the prevalence was similar in the region under study. Floridablanca municipality, free-ranging pigs, access to latrines, and consumption of spring water showed to be a risk factor for nematodes, while Giron municipality, pigs $>7$ months of age and access to latrines, increased infection risk for coccidian. We concluded that there is a high prevalence of gastrointestinal parasites in backyard pigs from the Bucaramanga Metropolitan Area, and that it could be controlled by improving management practices and farm facilities.
\end{abstract}

Keywords: Backyard pigs, gastrointestinal parasitism, nematodes, protozoan.

\begin{abstract}
Resumo
Suínos criados em fundo de quintal têm sido associados às más condições sanitárias e ao desenvolvimento de doenças parasitárias, frequentemente causando problemas de saúde pública e segurança alimentar. Assim, o objetivo deste estudo foi determinar a prevalência e os fatores de risco para parasitos gastrointestinais em suínos criados em fundo de quintal. Foram amostrados 279 animais de 32 fazendas de suínos localizadas nos municípios de Bucaramanga, Floridablanca, Giron e Piedecuesta, da Área Metropolitana de Bucaramanga, Colômbia. As amostras fecais foram coletadas diretamente do reto e processadas por quatro técnicas coprológicas. A prevalência geral de parasitos gastrintestinais foi de $91 \%$, sendo os maiores valores para Balantidium coli e Eimeria sp. Em relação à prevalência por municípios, não houve associação estatística $(p \geq 0,05)$, indicando que a prevalência foi semelhante na região estudada. O município de Floridablanca, porcos caipiras, acesso a latrinas e consumo de água da nascente mostraram ser um fator de risco para os nematoides enquanto no município de Giron, porcos com mais de 7 meses de idade e acesso a latrinas, aumentou o risco de infecção por coccídios. Concluiu-se que há uma alta prevalência de parasitos gastrointestinais em suínos criados em fundo de quintal da Área Metropolitana de Bucaramanga, e que isso poderia ser controlado melhorando as práticas de manejo e as instalações agrícolas.
\end{abstract}

Palavras-chave: Porcos caipiras, parasitismo gastrointestinal, nematóides, protozoários. 


\section{Introduction}

Gastrointestinal (Gl) parasitism is caused by different genera of parasites that inhabit the digestive tract of pigs, causing several digestive signs, loss of appetite, poor growth rate, poor feed conversion ratio, organ and carcass condemnation, high cost of treatment, economic losses in the farms, and even death in severe cases (Kagira et al., 2012). Therefore, parasites represent an obstacle in swine production, and thus, greater knowledge about the epidemiology is necessary (Góes et al., 2009). In general, Gl parasitism in pigs is caused by nematodes and protozoan (Cordero \& Rojas, 1999). Protozoan, Eimeria sp. and Cystoisospora suis, are enterococcidia which causes swine coccidiosis, an infection characterized by diarrhea in pigs under three months of age; also, parasitic infections by nematodes such as Ascaris suum, Trichuris suis, Strongyloides ransomi and parasites of the Strongylida order (Cordero \& Rojas, 1999). Many GI parasites affect health and swine production, and can be transmitted to humans, such as Balantidium coli, Entamoeba coli and Cryptosporidium sp. (Solaymani-Mohammadi \& Petri, 2006). These protozoans are transmitted via the fecal-oral route in both humans and animals, usually through the ingestion of contaminated water or food (Zheng et al., 2019).

Some authors have reported parasitic prevalences in backyard pigs. Mendoza-Gómez et al. (2015) reported prevalence rates of $40 \%$ for $E$. coli and $5 \%$ for B. coli in semi-technified farms from Cundinamarca department, Colombia, whilst Herrera et al. (2015) reported $97.5 \%$ of Gl parasitism (GIP) prevalence in Colombian creole pigs reared outdoors in the department of Cordoba. In a Mexican study, Kú et al. (2013) registered a general GIP prevalence of $71.9 \%$ in backyard pigs, whilst Cazorla Perfetti et al. (2013) found $66.4 \%$ of prevalence for protozoan and helminth parasites in pigs from a rural community in Venezuela, being $B$. coli (45.38\%) the most prevalent endoparasite. In the semi-arid region of northeastern Brazil, de Araújo et al. (2019) reported 79.5\% prevalence of gastrointestinal parasites, being coccidia (56.6\%) the most prevalent parasite recovered, followed by parasites of the Strongylida order (8.1\%). Roesel et al. (2017) conducted a study in small pig farms from Central and Eastern Uganda, Africa and reported a GIP prevalence of 61.4\%, being parasites of the Strongylida order and Eimeria sp. the most prevalent parasites.

In our country, pig farming is a technified industry that supplies the national market; however, backyard pig farming systems have been an alternative to generate economic income in many families in different regions of the country. The Santander department is located in the Colombian Northeast. This region is characterized by agricultural and cattle livestock production. According to the Colombian Agricultural Institute (ICA) the swine population census for the department was 93,000 pigs, being $85 \%$ in backyard and 30\% located in the Bucaramanga Metropolitan Area (ICA, 2017). Generally, this system is associated with a low socio-cultural and human health status, poor facilities, absence of veterinarian, poor sanitary conditions of the pig farms, lack of wastewater treatment, and the development of parasitic diseases in these species, often causing public health and food safety problems. In Colombia, there is little epidemiological information about GIP in pigs, especially in the Northeast region of the country, and for this reason, the aim of the present research was to determine the prevalence of GIP and risk factors in backyard pigs reared in the Bucaramanga Metropolitan Area, Colombia.

\section{Materials and Methods}

\section{Study area and sampling design}

The research was conducted in backyard pig farms located in the Bucaramanga Metropolitan Area, department of Santander, Northeast of Colombia, which consists in four municipalities: Bucaramanga $\left(7^{\circ} 07^{\prime} 07^{\prime \prime} \mathrm{N}-7^{\circ} 06^{\prime} 58^{\prime \prime} \mathrm{W}\right)$, Floridablanca $\left(7^{\circ} 04^{\prime} 11^{\prime \prime N}-73^{\circ} 05^{\prime} 52^{\prime \prime W}\right)$, Giron $\left(7^{\circ} 04^{\prime} 23^{\prime \prime} \mathrm{N}-73^{\circ} 10^{\prime} 05^{\prime \prime W}\right)$, and Piedecuesta $\left(6^{\circ} 59^{\prime} 19^{\prime \prime} \mathrm{N}-73^{\circ} 03^{\prime} 01^{\prime \prime W}\right)$ (Santander, 2017). This region comprises a geographical area of $1,479 \mathrm{~km}^{2}$. Rainfall is regular throughout the year; however, the most of their rainfall from October to December. Bioclimatic characteristics of the region are similar and with a mean annual temperature of $25^{\circ} \mathrm{C}$, with little weather variation throughout the year. Altitude is between 600 and 1700 masl and the mean annual rainfall is $1040 \mathrm{~mm}$, with $78 \%$ relative humidity (Santander, 2017). Within our study area, there is abundant evidence of backyard pig farms, as illustrated in Figure 1.

A random study, descriptive and transversal, was designed. Based in the ICA's vaccination records (ICA, 2017), the farms were selected for the study using a random number table method based on the geographic location. Thirty-two backyard pig farms were visited between September and December 2019 (wet period). Figure 2 shows the Bucaramanga Metropolitan Area, department of Santander, and the location of the farms surveyed (black dots). Most of the pigs sampled were cross-breeds between the Yorkshire, Landrace and Pietrain breeds. 


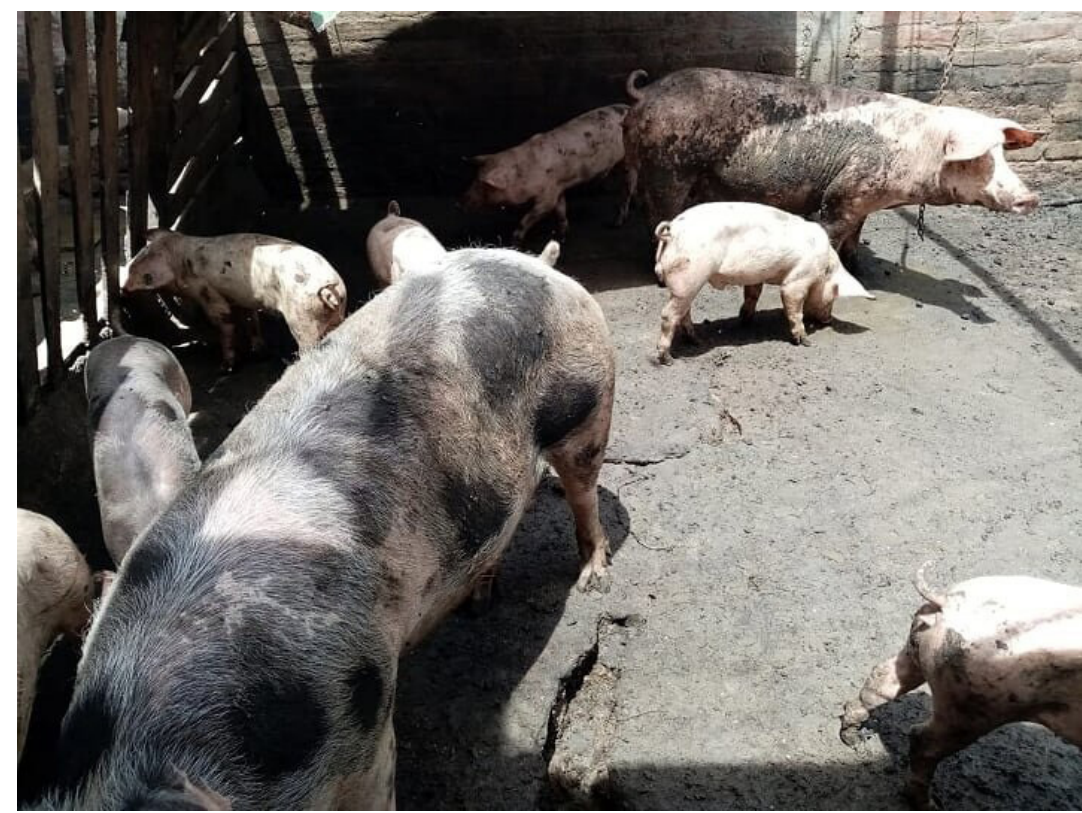

Figure 1. Backyard pigs group raised in open-air pens on farms located at the Bucaramanga Metropolitan Area, department of Santander, Colombia.

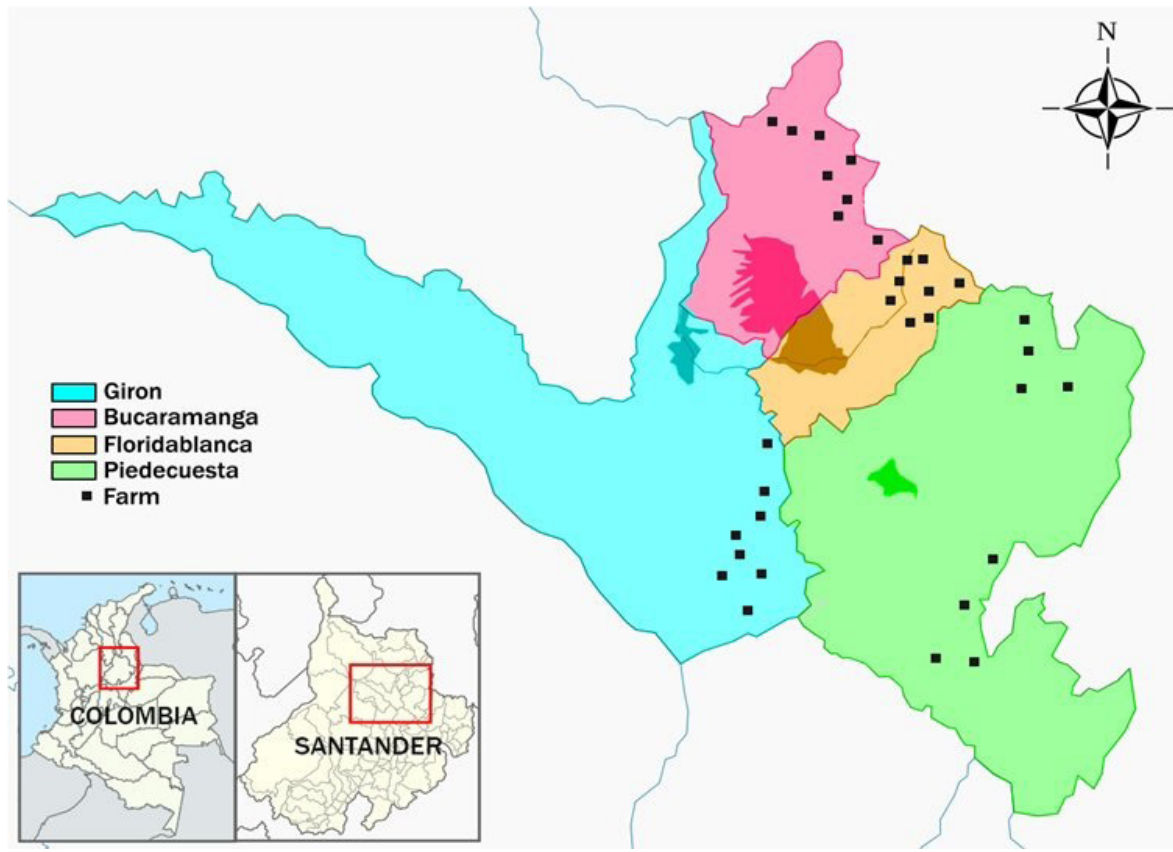

Figure 2. Bucaramanga Metropolitan Area map showing the locations of the farms surveyed (black dots). Bottom left shows Santander department and Colombia.

Approximately $5-10 \mathrm{~g}$ of feces were collected weekly from the rectum of each pig, using previously labeled sterile polyethylene bags. In suckling piglets, a swab was introduced rectally to collect a small fecal sample. Samples were placed into containers filled with ice packs and immediately transported to the laboratory for processing. Using the formula for known populations (Thrusfield, 2007), with an expected prevalence of 50\% (Pulido-Villamarín et al., 2013), and a confidence level of $95 \%$ with $6 \%$ of associated maximum error, an estimated sample size of 266 fecal samples was required to estimate the gastrointestinal prevalence of parasites in backyard pigs in this region. Fecal samples were collected by proportional affixation of total sample according to the inventory from each examined farm. Therefore, the range was between 4 to 20 samples per farm, with an average of 8.7, providing samples from 279 pigs. The number of pigs to be sampled by sex was defined by a 2:1 ratio (female: male), whilst it was considered a $25 \%( \pm 5 \%)$ frequency of the total sample for each age group. 


\section{Risk factors}

Epidemiological data about potential risk factors were obtained using a questionnaire administered to the owner or manager of each herd at the time fecal samples were collected. This data in the questionnaire included: municipality where the farm is located, age group of the examined animals ( $\leq 2$ months, 3-6 months, 7-12 months, and $\geq 13$ months), sex, i.e. male and females, pigs free-ranging, location of the farm, the quantity of animals of the farm, pig access to latrines, de-wormed, type of feed supplied to the pigs and water source for the animals.

\section{Laboratory analysis}

Some of the fecal material was immediately processed for direct examination with lugol's iodine solution (1:5 dilutions) to determine $B$. coli and $E$. coli cysts, as described by Rodríguez-Vivas (2015). Then, all fecal samples were cultured at room temperature, as described by Pinilla \& Da Silva (2019). A centrifugation-flotation technique and McMaster technique were then used according to Pinilla \& Da Silva (2019) and Sandoval et al. (2011), respectively. The numbers of opg (oocysts per gram of feces) and epg (eggs per gram of feces) on the McMaster slides were calculated with a detection level of 100 (one chamber) which is the standardized factor for this technique. The intensity of infection was determined as indicated by Sandoval et al. (2011). Finally, the Kinyoun technique was employed to detect Cryptosporidium sp. oocysts, as described by Rodríguez-Vivas (2015). The parasitic species observed were identified by the morphology of their eggs and oocysts using a light optical microscope with a magnification of 40 and 100x (Rodríguez-Vivas, 2015).

\section{Data analysis}

The information obtained through the coprological techniques and epidemiological questionnaires were stored in a database that was created using the Microsoft Excel software. The GIP prevalence was determined by dividing the number of positive animals between the total animal populations of the sampled population. The results obtained were analyzed by descriptive statistics and the Chi square test $\left(X^{2}\right)$. Predictor variables with $p$-value $\leq$ 0.05 in the Chi-square test (Hosmer \& Lemeshow, 2000) were selected for multiple analysis using logistic regression with confidence intervals ( $95 \%$ confidence level). The level of significance for the analyzes was $5 \%$. Calculations were made using the SPSS v.20.0 software (@ 2011 IBM corporation, United States)

\section{Ethical statement}

The present study was approved by the Ethics Committee of the University of Santander, under initiation act no. CIF0311-19.

\section{Results}

The overall prevalence of GIP in the Bucaramanga Metropolitan Area was 91\% (254/279). No statistical association was found $\left(X^{2}=0.76 ; p \geq 0.05\right)$ between prevalence values in the four municipalities: $89.2 \%$ (83/93) in Bucaramanga, 91.5\% (43/47) in Floridablanca, 91.1\% (72/79) in Giron and 93.3\% (56/60) in Piedecuesta. With regard to the farms, at least one pig was positive for GIP on each examined farm, with $71.9 \%$ of farms positive to nematodes and $100 \%$ to protozoan.

Table 1 shows the 9 parasite species found in the study, being B. coli, Eimeria sp., E. coli, and parasites of the order Strongylida being the most prevalent. With concerning to intensity of infection, $S$. ransomi showed the highest level, followed by A. suum, Eimeria sp. oocysts and T. suis. Cryptosporidium sp. oocysts were not counted. No clinical signs of parasitic infection were observed in examined pigs. In most (78.1\%) of the fecal samples examined, two or more parasite genus were evidenced, whilst in $21.9 \%$ of the cases, just one parasite genera were found.

Table 2 and Table 3 shows the analysis of the owner's information (epidemiological data) associated with nematode and protozoan infections in backyard pigs, respectively. In the univariate analysis, most categories for nematodes parasitism showed $p \leq 0.05$, except for the number of pigs. Regarding coccidian infections, categories that showed $p \leq 0.05$ were Giron municipality, pigs $>7$ months, the altitude at $<1000$ masl, and de-worming of the animals, whilst for E. coli were Floridablanca municipality and altitude at $>1000$ masl. Cryptosporidium sp. showed a statistical association with pig access to latrines, while $B$. coli did not show a statistical association with any category. 
Table 1. Prevalence and intensity of gastrointestinal parasites obtained from the fecal samples of backyard pigs in the Bucaramanga Metropolitan Area, department of Santander, Colombia.

\begin{tabular}{cccc}
\hline Parasite & Positive $(\mathbf{n = 2 7 9 )}$ & Prevalence (\%) & Intensity of infection (opg - epg) \\
\hline Protozoan group & 147 & 52.7 & 260.3 \\
Balantidium coli & 140 & 50.2 & 1230 \\
Eimeria sp. & 94 & 33.7 & 100 \\
Entamoeba coli & 16 & 5.7 & \multirow{2}{*}{} \\
Cryptosporidium sp. & 5 & 1.8 & 357.1 \\
Cystoisospora suis & & & 244.4 \\
Nematodes group & 36 & 12.9 & 3762.5 \\
Strongylida** & 12 & 4.3 & 2150 \\
Strongyloides ransomi & 11 & 3.9 & 400 \\
Ascaris suum & 5 & 1.8 & 4 \\
Trichuris suis & 5 & \\
\hline
\end{tabular}

* Cryptosporidium sp. was no counted; ** as Strongylida order

Table 2. Association between risk factors and nematode parasitism in backyard pigs reared in the Bucaramanga Metropolitan Area.

\begin{tabular}{|c|c|c|c|c|}
\hline Risk factors & Categories & $\mathbf{N}^{\circ}$ & Positive (\%) & p-value \\
\hline \multirow[t]{4}{*}{ Municipality } & B/manga & 93 & $64(68.8)$ & \\
\hline & Floridablanca & 47 & $47(100)$ & \\
\hline & Piedecuesta & 60 & 7 (11.7) & \\
\hline & Giron & 79 & $65(82.3)$ & $0.000 *$ \\
\hline \multirow[t]{4}{*}{ Age group } & $\leq 2$ months & 71 & $54(76.1)$ & \\
\hline & 3-6 months & 49 & $23(46.9)$ & \\
\hline & 7-12 months & 88 & $67(76.1)$ & \\
\hline & $\geq 13$ months & 71 & $39(54.9)$ & $0.000 *$ \\
\hline \multirow[t]{2}{*}{ Sex } & Male & 107 & 79 (73.8) & \\
\hline & Female & 172 & $104(60.5)$ & $0.02^{*}$ \\
\hline \multirow[t]{2}{*}{ Altitude } & $<1000$ & 139 & $122(87.8)$ & \\
\hline & $>1000$ & 140 & $61(43.6)$ & $0.00 *$ \\
\hline \multirow[t]{2}{*}{ Free-ranging pigs } & No & 213 & $117(54.9)$ & \\
\hline & Yes & 66 & $66(100)$ & $0.00 *$ \\
\hline \multirow[t]{2}{*}{ Access to latrines } & No & 257 & $161(62.6)$ & \\
\hline & Yes & 22 & $22(100)$ & $0.00 *$ \\
\hline \multirow[t]{2}{*}{ Number of pigs } & $<10$ & 82 & $60(73.2)$ & \\
\hline & $>10$ & 197 & $123(62.4)$ & 0.09 \\
\hline \multirow[t]{2}{*}{ De-worming } & No & 17 & $17(100)$ & \\
\hline & Yes & 262 & $166(63.4)$ & $0.002 *$ \\
\hline \multirow[t]{3}{*}{ Type of food } & Restaurant residues & 60 & $41(68.3)$ & \\
\hline & Concentrate & 56 & 19 (33.9) & \\
\hline & Mixed & 163 & $123(75.5)$ & $0.000 *$ \\
\hline \multirow[t]{2}{*}{ Water source } & Deep well water & 214 & $121(56.5)$ & \\
\hline & Spring water & 65 & $62(95.4)$ & $0.000 *$ \\
\hline
\end{tabular}

*Variables that presented a value of $p \leq 0.05$ by the Chi-square test. 
Table 3. Association between risk factors and protozoan infection in backyard pigs reared in the Bucaramanga Metropolitan Area.

\begin{tabular}{|c|c|c|c|c|c|c|c|c|c|c|}
\hline \multirow{2}{*}{ Risk factors } & \multirow{2}{*}{ Categories } & \multirow{2}{*}{$\mathbf{N}^{\circ}$} & \multirow{2}{*}{$\begin{array}{c}\text { Coccidia** } \\
\begin{array}{c}\text { Positive } \\
(\%)\end{array}\end{array}$} & \multirow{2}{*}{$\frac{\frac{0}{2}}{\frac{2}{\pi}}$} & \multirow{2}{*}{$\begin{array}{c}\begin{array}{c}\text { Cryptosporidium } \\
\text { sp. }\end{array} \\
\text { Positive (\%) }\end{array}$} & \multirow{2}{*}{ p-value - } & \multirow{2}{*}{$\begin{array}{c}\begin{array}{c}\text { Balantidium } \\
\text { coli }\end{array} \\
\text { Positive (\%) }\end{array}$} & \multirow{2}{*}{$\frac{0}{\frac{0}{\pi}}$} & \multirow{2}{*}{$\begin{array}{c}\text { Entamoeba } \\
\text { coli }\end{array}$} & \multirow{2}{*}{$\frac{\frac{0}{2}}{\frac{2}{\pi}}$} \\
\hline & & & & & & & & & & \\
\hline \multirow[t]{4}{*}{ Municipality } & B/manga & 93 & $42(45.2)$ & & $6(6.5)$ & & $44(47.3)$ & & $18(19.4)$ & \\
\hline & Floridablanca & 47 & $19(40.4)$ & & $4(8.5)$ & & $27(57.4)$ & & $23(48.9)$ & \\
\hline & Piedecuesta & 60 & $30(50)$ & & $2(3.3)$ & & 31 (51.7) & & $22(36.7)$ & \\
\hline & Giron & 79 & $51(64.6)$ & $0.03^{*}$ & $4(5.1)$ & 0.69 & $45(57)$ & 0.55 & 31 (39.2) & $0.002^{*}$ \\
\hline \multirow[t]{4}{*}{ Age group } & $\leq 2$ months & 71 & $26(36.6)$ & & $2(2.8)$ & & 35 (49.3) & & $23(32.4)$ & \\
\hline & 3-6 months & 49 & $22(44.9)$ & & $1(2)$ & & $22(44.9)$ & & $14(28.6)$ & \\
\hline & 7-12 months & 88 & $54(61.4)$ & & $9(10.2)$ & & $50(56.8)$ & & 31 (35.2) & \\
\hline & $\geq 13$ months & 71 & $40(56.3)$ & $0.01 *$ & $4(5.6)$ & 0.13 & $40(56.3)$ & 0.47 & $26(36.6)$ & 0.8 \\
\hline \multirow[t]{2}{*}{ Sex } & Male & 107 & $51(47.7)$ & & $7(6.5)$ & & $60(56.1)$ & & $36(33.6)$ & \\
\hline & Female & 172 & 91 (52.9) & 0.39 & $9(5.2)$ & 0.65 & 87 (50.6) & 0.37 & $58(33.7)$ & 0.9 \\
\hline \multirow[t]{2}{*}{ Altitude } & $<1000$ & 139 & $84(60.4)$ & & $7(5)$ & & 68 (48.9) & & $39(28.1)$ & \\
\hline & $>1000$ & 140 & $58(41.4)$ & $0.02 *$ & $9(6.4)$ & 0.62 & 79 (56.4) & 0.21 & 55 (39.3) & $0.04 *$ \\
\hline \multirow{2}{*}{$\begin{array}{c}\text { Free-ranging } \\
\text { pigs }\end{array}$} & No & 213 & $113(53.1)$ & & $12(5.6)$ & & $112(52.6)$ & & $69(32.4)$ & \\
\hline & Yes & 66 & 29 (43.9) & 0.19 & $4(6.1)$ & 0.89 & $35(53)$ & 0.95 & 25 (37.9) & 0.41 \\
\hline \multirow{2}{*}{$\begin{array}{l}\text { Access to } \\
\text { latrines }\end{array}$} & No & 257 & $134(52.1)$ & & $12(4.7)$ & & $133(51.8)$ & & $88(34.2)$ & \\
\hline & Yes & 22 & $8(36.4)$ & 0.15 & $4(18.2)$ & $0.009 *$ & $14(63.6)$ & 0.28 & $6(27.3)$ & 0.5 \\
\hline \multirow{2}{*}{$\begin{array}{c}\text { Number of } \\
\text { pigs }\end{array}$} & $<10$ & 82 & $38(46.3)$ & & $8(9.8)$ & & $40(48.8)$ & & $24(29.3)$ & \\
\hline & $>10$ & 197 & $104(52.8)$ & 0.32 & $8(4.1)$ & 0.06 & 107 (54.3) & 0.4 & $70(35.5)$ & 0.31 \\
\hline \multirow[t]{2}{*}{ De-worming } & No & 17 & $2(11.8)$ & & $1(5.9)$ & & $9(52.9)$ & & $6(35.3)$ & \\
\hline & Yes & 262 & $140(53.4)$ & $0.01 *$ & $15(5.7)$ & 0.9 & $138(52.7)$ & 0.9 & 88 (33.6) & 0.88 \\
\hline \multirow[t]{3}{*}{ Type of food } & $\begin{array}{l}\text { Restaurant } \\
\text { residues }\end{array}$ & 60 & $26(43.3)$ & & $2(3.3)$ & & $34(56.7)$ & & $24(40)$ & \\
\hline & Concentrate & 56 & $34(60.7)$ & & $2(3.6)$ & & $26(46.4)$ & & $12(21.4)$ & \\
\hline & Mixed & 163 & $82(50.3)$ & 0.17 & $12(7.4)$ & 0.38 & $87(53.4)$ & 0.5 & $58(35.6)$ & 0.08 \\
\hline \multirow[t]{2}{*}{ Water source } & Spring water & 65 & $28(43.1)$ & & $2(3.1)$ & & $30(46.2)$ & & $22(33.8)$ & \\
\hline & $\begin{array}{l}\text { Deep well } \\
\text { water }\end{array}$ & 214 & $114(53.3)$ & 0.15 & $14(6.5)$ & 0.3 & $117(54.7)$ & 0.2 & 72 (33.6) & 0.9 \\
\hline
\end{tabular}

\footnotetext{
* Variables that presented a value of $\mathrm{p} \leq 0.05$ by the Chi-square test. ** As Coccidia (Eimeria sp. and Cystoisospora suis)
}

Regarding risk factors (Table 4) for the occurrence of nematodes parasitism, pigs from Floridablanca and Giron municipalities showed $41.5(\mathrm{OR}=41.5, \mathrm{Cl} 95 \%=20.1-54.3)$ and $2.1(\mathrm{OR}=2.1, \mathrm{Cl} 95 \%=1.01-4.3)$ times higher risk of infection, respectively. Free-ranging pigs and access to latrines showed $1.96(\mathrm{OR}=1.96, \mathrm{Cl} 95 \%=0.8-2.34)$ and $1.91(\mathrm{OR}=1.91, \mathrm{Cl} 95 \%=0.75-3.2)$ times higher probability for infection, respectively. Animals consuming spring water showed $15.8(\mathrm{OR}=15.8, \mathrm{Cl} 95 \%=4.8-52.2)$ times higher probability for infection. For coccidian infections, pigs from Giron municipality showed $2.2(\mathrm{OR}=2.2, \mathrm{Cl} 195 \%=1.2-4.1)$ times higher probability of infection, whilst animals from 7 to 12 months and $\geq 13$ months showed $2.8(\mathrm{OR}=2.8, \mathrm{Cl} 95 \%=1.4-5.2)$ and 2.3 times higher risk for coccidian infections, respectively. Those pigs with access to latrines had 4.5 times more likely to be exposed $(\mathrm{OR}=4.5, \mathrm{Cl} 95 \%=1.3-15.5)$ for Cryptosporidium sp. infection 
Table 4. Multiple analysis regression of the risk factors associated with nematode and protozoan infection in backyard pigs reared in the Bucaramanga Metropolitan Area.

\begin{tabular}{|c|c|c|c|c|c|}
\hline Risk factors & B & E. $\mathbf{T}$ & $\operatorname{Exp}(\beta)$ & $\mathrm{Cl}(95 \%)$ & p-value \\
\hline \multicolumn{6}{|l|}{ Nematodes } \\
\hline Floridadablanca municipality & 20.4 & 58.6 & 41.5 & 20.1-54.3 & 0.000 \\
\hline Free-ranging pigs (yes) & 0.65 & 0.1 & 1.96 & $0.8-2.34$ & 0.000 \\
\hline Access to latrines (yes) & 0.6 & 0.12 & 1.91 & $0.75-3.2$ & 0.01 \\
\hline Spring water & 2.7 & 0.67 & 15.8 & $4.8-52.2$ & 0.02 \\
\hline \multicolumn{6}{|l|}{ Coccidia* } \\
\hline Giron municipality & 0.8 & 0.3 & 2.2 & $1.2-4.1$ & 0.01 \\
\hline $7-12$ months of age & 1.01 & 0.33 & 2.8 & $1.4-5.2$ & 0.002 \\
\hline$\geq 13$ months of age & 0.8 & 0.34 & 2.3 & $1.1-4.3$ & 0.02 \\
\hline \multicolumn{6}{|l|}{ Cryptosporidium sp. } \\
\hline Access to latrines (yes) & 1.5 & 0.63 & 4.5 & $1.3-15.5$ & 0.01 \\
\hline
\end{tabular}

$\mathrm{B}=$ Estimated value B; E.T = Standard error; $\operatorname{Exp}(\beta)=\mathrm{OR} ; \mathrm{Cl}=$ Confidence interval. * as Coccidia (Eimeria sp. and Cystoisospora suis).

\section{Discussion}

The GIP in pigs is considered one of the most important problems in pig farming since they causing reduce weight, organ condemnation, high morbidity in young animals and even death in severe cases (Cordero \& Rojas, 1999; Kagira et al., 2012). In Colombia, there is little epidemiological information on GIP in pigs, at least in the consulted literature and for this reason, the data about the GIP in pigs are still unknown.

The prevalence of GIP found in the four municipalities were similar, since the temperature and humidity conditions in the zone, the management in most of the farms as well as the programs in the control of infectious agents are very much the same in the four municipalities (Cordero \& Rojas, 1999). On the other hand, the high individual prevalence of GIP found in this study indicates the absence of hygienic and sanitary management in the examined farms, where some risk factors may have favored the dissemination and transmission of parasites among animals. The results obtained in this research agree with those reported by Kú et al. (2013) who found a prevalence of $71.9 \%$ in backyard farms in the state of Yucatan, Mexico. Furthermore, the result obtained agree with those from Cazorla Perfetti et al. (2013), who reported similar values of prevalence for protozoan and helminths in pigs from a rural community in Venezuela. Similarly, the high prevalence of GIP found in the present study, agree with the findings of Herrera et al. (2015) in Colombia, Roesel et al. (2017) in Uganda, and de Araújo et al. (2019) in Brazil, who reported $97.5 \%, 61.4 \%$ and $79.5 \%$ prevalence of gastrointestinal parasites, respectively.

The present study found 9 parasitic species, being protozoan infections the most prevalent. In addition, some of these protozoan (B. coli and $E$. coli) are zoonotic in nature and can infect humans. The results obtained in this study agree with those of Pinto et al. (2007), who reported the same number of parasitic species (9). Also, these results agree with those of Herrera et al. (2015), who reported more than 12 parasite genera in their studies. According to Cordero \& Rojas (1999), mixed parasitic infections in pigs are very common in backyard pig farming, and it seems to be an indication of high environmental pollution of the pig population (Herrera et al., 2015), whilst monospecies infections are less frequent, and are registered for the effect of climate change in a given region, as well as, in hosts under intensive parasite control. In the present study, $78.1 \%$ of the pigs examined were parasitized by two or more parasite genus, whilst $21.9 \%$ had one parasite genera. This result agrees with those recorded by Cazorla Perfetti et al. (2013) and Herrera et al. (2015), who found a high degree of polyparasitism in their studies. This could be due to the fact that backyard pig rearing system allows that all age groups of animals are raised together, increasing the dissemination odds of mixed infections in all animals. Although the mean intensity of infection for $B$. coli and $E$. coli found in this study, are considered mild, a more severe infection was observed for Eimeria sp., S. ransomi and A. suum, however, no clinical signs were observed in the examined pigs. According to Aguiar (2009) and de Araújo et al. (2019), subclinical infections are important and can be frequent, affecting animals by causing loss of appetite, low weight gain, and reduced feed conversion. 
The present study found that B. coli was most prevalent (52.7\%), followed by Eimeria sp. (50.2\%) and E. coli (33.7\%). These results obtained agree with those recorded by Pinto et al. (2007), who revealed similar values of prevalence in these parasites. Similarly, the results obtained in this study agree with those reported of Cazorla Perfetti et al. (2013) and Gúzman et al. (2013), who found similar prevalence values for B. coli in outdoor pigs from Venezuela. However, the results obtained differ from those reported of Mendoza-Gómez et al. (2015), who found 5\% of prevalence for $B$. coli in farms from Cundinamarca state, Colombia. The prevalence of $E$. coli in the present study was 33.7\%, and this result agrees with those reported by Mendoza-Gómez et al. (2015), who found 40\% of prevalence in pigs from Cundinamarca state. Although $E$. coli do not cause infection, their presence indicates the fecal-oral transmission in the host, which is an indicator for the general assessment of the hygiene status of the animals. The high prevalence mentioned, could be caused for the ingestion of contaminated water or food, or by immunosuppression in the animals due to factors like stress associated with overcrowding.

In relation to Cryptosporidium sp. the prevalence rate found was 5.7\% (16/279). This result agrees with those of Mendoza-Gómez et al. (2015), who found similar prevalence values in semi-technified farms. Cryptosporidium sp. infections are common in pigs and have been found in all age groups worldwide. Although the age distribution of Cryptosporidium infection rates in pigs has not been clearly concluded, it can be assumed that the prevalence in pigs aged 1-2 months is greater than that of other age groups by the weaning effect (Zheng et al., 2019). Cryptosporidiosis is a disease of high zoonotic importance, known as a public health problem, that affects mainly people that interact with farm animals daily. Therefore, it is important to demonstrate the presence of this pathogen with zoonotic potential, to take measures such as strengthening the breeding management of pigs and improving the sanitary control to avoid the spread of pathogens (Zheng et al., 2019).

As for the nematode groups, parasite genera grouped under the Strongylida order showed the highest prevalence values in this group (12.9\%), whilst S. ransomi showed low prevalence (4.3\%) and the frequency was moderate (18.7\%). This could be since during the life cycle of Strongyloides sp., cutaneous and colostral transmission is possible and, poor hygiene conditions in the farms favor a greater risk of infection of the pigs. The prevalence of $A$. suum (3.9\%) and $T$. suis (1.8\%) were low. These results could be due to the fact that the pig can develop an immune response to these parasites, however, residual loads may remain in the infected animals (Murrell, 1986; Kringel \& Roepstorff, 2006; Nejsum et al., 2009; Nwafor et al., 2019).

Regarding risk factors associated with gastrointestinal nematodes, backyard pigs from Floridablanca municipality had a $41.5(\mathrm{OR}=41.5 ; \mathrm{p} \leq 0.05)$ times higher risk of infection than other locations. This municipality is located at medium altitudes (1000 to 1700 masl), with mean annual temperature $\left(25\right.$ to $\left.30^{\circ} \mathrm{C}\right)$ long the year, with prolonged periods of rain and average precipitation rates between 1100 and $1400 \mathrm{~mm}$, which are favorable climatological conditions for the presence of GIP and increased risk of infection for the animals. Free-ranging pigs and access to latrines showed to be a risk factor for nematode infection. These results agree with those reported by Thomas et al. (2013), who found a positive correlation between the Ascaris sp. infection and the interacting with latrines, and a moderate positive correlation between coccidia infection and home range area. Probably, pigs free-ranging when have access to latrines could have higher contact with paratenic hosts as earthworms or scarabaeus, and therefore, increase the parasitic disease transmission risk to the pig itself and, to other wild and domestic animals, even humans (Thomas et al., 2013).

The consumption of spring water showed 15.8 times increased risk of infection for gastrointestinal nematodes. A study conducted by Morales et al. (2015) revealed that most of the backyard pig farming had no solid effluents treatment, since they keep them inside or outside the farm, causing serious problems of spring water contamination, flies and pathogens, and a health problem for people and animals. Therefore, polluted spring water can transmit lots of pathogens with various behaviors and resistance to various environmental factors. Probably, the lack of wastewater treatment in backyard pig farming represents a serious environmental and social problems due to the contamination of the spring water and soil that are around it, which are also accompanied by swine waste odor (Morales et al., 2015).

In relation to coccidian infections, the animals raised in farms from Giron municipality had 2.2 times the risk of becoming infected than pigs from other locations. According to Cordero \& Rojas (1999), Eimeria sp. and C. suis oocysts are favored by rainfall and temperature of the zone, poor facilities and poor hygiene of the farm, as well as, the high biotic potential of the coccidia. Probably, the high prevalence $(64.6 \%)$ of these protozoans found in this study is associated with the wet period of the year when fecal samples were collected, since in this municipality was observed the most rainfall during the sampling period. Moreover, most of the examined farms in this municipality showed poor facilities and poor hygienic and sanitary conditions. The animals $>7$ months of age showed to be a risk 
factor for coccidian infections and could behave as asymptomatic carriers and act as a potential source of infection for piglets, causing eimeriosis, since they become infected by ingesting sporulated oocysts with feed or water, or by any parasitic dissemination mechanism such as people, overall, boots and intermediate host (Quiroz et al., 2011).

In our study, the access to latrines showed to be a risk factor ( $O R=4.5 ; \mathrm{p} \leq 0.05)$ for Cryptosporidium $\mathrm{sp}$. in pigs, since this pathogen is transmitted via the fecal-oral route in humans and animals, usually through the ingestion of contaminated water or food with feces (Chacín-Bonilla et al., 2008). Probably, the contact with infective human fecal material by pigs is an important requisite for the successful maintenance of the parasite lifecycle, therefore, it would be to think stands to reason that keeping free-ranging pigs in contact with latrines, it would increase the risk of the pigs in acquiring this infection, as in other parasitic infections (Thomas et al., 2013). In developing countries, the environmental risk factors and routes of transmission for Cryptosporidium sp. infection are not well defined. Despite the numerous surveillance studies reported, few investigations have been conducted about the source of infection. However, contamination of water supplies and infection of domestic animals, lacking adequate municipal water and sewage services, and using a field or latrine for defecation in human communities were correlated with a higher risk of cryptosporidiosis (Chacín-Bonilla et al., 2008).

\section{Conclusion}

It was concluded that the high overall prevalence of GI parasitism reported in this study could be due to poor facilities, and lack of hygiene in the facilities. To our knowledge, the present research recorded B. coli, E. coli, and Cryptosporidium sp. for the first time in the region under study, and suggests the possible transmission of these parasite populations between pigs and humans thus increasing the transmission of parasites zoonotic potential. The relevant risk factors for nematodes included free-ranging pigs and consumption of spring water, while for Cryptosporidium sp., access to latrines was a relevant risk factor

\section{Acknowledgements}

The authors thank the University of Santander, Colombia for financial support for this project. The authors thank the staff of Veterinary Clinic Research Laboratory of the University of Santander, Colombia for their help in the conduction of this project.

\section{References}

Aguiar Cl. Aspectos epidemiológicos das parasitoses gastrintestinais de suínos naturalizados de criações familiares do Distrito Federal [dissertação]. Brasília: Universidade de Brasília; 2009.

Cazorla Perfetti DJ, Acosta Quintero ME, Tortolero Low JL, Moreno PM. Prevalencia de enteroparásitos porcinos en una comunidad rural de la península de Paraguaná, estado Falcón, Venezuela. Rev Cient FCV-LUZ 2013; 23(1): $19-25$.

Chacín-Bonilla L, Barrios F, Sanchez Y. Environmental risk factors for Cryptosporidium infection in an island from Western Venezuela. Mem Inst Oswaldo Cruz 2008; 103(1): 45-49. http://dx.doi.org/10.1590/S0074-02762008005000007.

Cordero CM, Rojas F. Parasitología Veterinaria. España: Mc Graw Hill; 1999.

de Araújo HG, da Silva JT, Álvares FBV, Ferreira LC, Azevedo SS, Vilela VL. Prevalence and risk factors associated with swine gastrointestinal nematodes and coccidia in the semi-arid region of northeastern Brazil. Trop Anim Health Prod 2019; 52(1): 379385. http://dx.doi.org/10.1007/s11250-019-02032-8.

Góes G, Santos TB, de Melo CM, Jeraldo VLS. Ocorrência de enteroparasitas em amostras fecais de suínos do município de Simão Dias-SE. Cad Grad- Ciênc Biol Saúde 2009; 1(15): 11-18.

Guzmán RC, Nessi PA, González OH, Hernández MO, Galindo M, Dorta A, et al. Balantidium spp in pigs and their keepers: Prevalence in communities of two States of Venezuela. VITAE Acád Biom Dig 2013; 54.

Herrera BY, Almanza PM, Ensuncho HC, Goméz ML, Galeano EM. Determinación coprológica de la parasitofauna en cerdos criollos (Sus scrofa domestica) en el departamento de Córdoba, Colombia. Rev Colombiana Cienc Anim 2015; 7(2): 160-164. http:// dx.doi.org/10.24188/recia.v7.n2.2015.257.

Hosmer DW, Lemeshow S. Applied logistic regression. New York: John Wiley e Sons; 2000. http://dx.doi.org/10.1002/0471722146. Instituto Colombiano Agropecuario - ICA. Vigilancia Epidemiológica. Censo Pecuario Nacional [online]. Bogotá: ICA; 2017 [cited 2020 Feb 5]. Available from: https://www.ica.gov.co/areas/pecuaria/servicios/epidemiologia-veterinaria/censos-2016/censo-2017.aspx 
Kagira JM, Kanyari PN, Githigia SM, Maingi N, Nganga JC, Gachohi JM. Risk factors associated with occurrence of nematodes in free range pigs in Busia District, Kenya. Trop Anim Health Prod 2012; 44(3): 657-664. http://dx.doi.org/10.1007/s11250-011-9951-9.

Kringel H, Roepstorff A. Trichuris suis population dynamics following a primary experimental infection. Vet Parasitol 2006; 139(13): 132-139. http://dx.doi.org/10.1016/j.vetpar.2006.03.002.

Kú R, Trejo W, Aguilar A, Belmar R, Castillo J. Parasitismo gastrointestinal en el cerdo pelón mexicano en traspatio en el estado de Yucatán, México. Rev Colombiana Cienc Anim 2013; 6(1): 17-24.

Mendoza-Gómez M, Pulido-Villamarín A, Barbosa-Buitrago A, Aranda-Silva M. Presence of gastrointestinal parasites in swine and human of four swine production farms in Cundinamarca- Colombia. Rev Mvz Cordoba 2015; 20(1): 5014-5027. http://dx.doi. org/10.21897/rmvz.15.

Morales R, Rebatta M, Lucas J, Mateo J, Ramos D. Caracterización de la crianza no tecnificada de cerdos en el parque porcino del distrito de Villa el Salvador, Lima-Perú. Salud Tecnol Vet 2015; 2(1): 39-48. http://dx.doi.org/10.20453/stv.v2i1.2206.

Murrell KD. Epidemiology, pathogenesis and control of major swine helminth parasites. Vet Clin North Am Food Anim Pract 1986; 2(2): 439-454. http://dx.doi.org/10.1016/S0749-0720(15)31255-X.

Nejsum P, Roepstorff A, Jørgensen CB, Fredholm M, Göring HHH, Anderson TJC, et al. High heritability for Ascaris and Trichuris infection levels in pigs. Heredity 2009; 102(4): 357-364. http://dx.doi.org/10.1038/hdy.2008.131.

Nwafor IC, Roberts H, Fourie P. Prevalence of gastrointestinal helminths and parasites in smallholder pigs reared in the central Free State Province. Onderstepoort J Vet Res 2019; 86(1): a1687. http://dx.doi.org/10.4102/ojvr.v86i1.1687.

Pinilla JC, Da Silva N. Infection dynamics of Cystoisospora suis (Isospora suis) on a pilot swine farm in Carabobo State, Venezuela. Rev Mex Cienc Pecu 2019; 10(1): 149-160. http://dx.doi.org/10.22319/rmcp.v10i1.4487.

Pinto JM, Costa JO, Souza JC. Ocorrência de endoparasitos em suínos criados em Itabuna, Bahia, Brasil. Ciênc Vet Tróp 2007; 10(2-3): 79-85.

Pulido-Villamarín A, Barbosa-Buitrago A, Hernández-Gallo N, Mendoza-Gómez M, Ortiz-Rincón I, García-Fonseca S. Potencial zoonotic parasites found in six swine farms of Cundinamarca, Colombia. Neotrop Helminthol 2013; 7(1): 51-63.

Quiroz H, Figueroa J, Ibarra F, López M. Epidemiología de enfermedades parasitarias en animales domésticos. México, DF: Revista Facultad Medicina Veterinaria y Zootecnia UNAM; 2011.

Rodríguez-Vivas RI. Técnicas para el diagnóstico de parásitos con importancia en salud pública y veterinaria. México, DF: AmpaveConasa; 2015

Roesel K, Dohoo I, Baumann M, Dione M, Grace D, Clausen P-H. Prevalence and risk factors for gastrointestinal parasites in small-scale pig enterprises in Central and Eastern Uganda. Parasitol Res 2017; 116(1): 335-345. http://dx.doi.org/10.1007/s00436-016-5296-7.

Sandoval E, Morales G, Ybarra N, Barrios M, Borges J. Comparación entre dos modelos diferentes de cámaras de McMaster empleadas para el conteo coproscópico en el diagnóstico de infecciones por nematodos gastroentéricos en rumiantes. Zootec Trop 2011; 29(4): 495-501.

Santander. Municipios del Departamento de Santander. [online] Santander, Colombia; 2017 [cited 2020 Jan 15]. Available from: http://www.santander.gov.co/index.php/atencion-al-ciudadano/directorios/directorio-municipios

Solaymani-Mohammadi P, Petri WAJr. Zoonotic implications of the swine-transmitted protozoal infections. Vet Parasito/ 2006;140(34): 189-203. https://doi.org/10.1016/j.vetpar.2006.05.012

Thomas LF, de Glanville WA, Cook EA, Fèvre EM. The spatial ecology of free-ranging domestic pigs (Sus scrofa) in western Kenya. BMC Vet Res 2013;9:46. https://doi.org/10.1186/1746-6148-9-46.

Thrusfield M. Veterinary epidemiology. Oxford: Wiley Blackwell; 2007.

Zheng S, Li D, Zhou C, Zhang S, Wu Y, Chang Y, et al. Molecular identification and epidemiological comparison of Cryptosporidium spp. among different pig breeds in Tibet and Henan, China. BMC Vet Res 2019; 15(1): 101. http://dx.doi.org/10.1186/s12917019-1847-3. 